\title{
Synthesis of PAMAM Dendrimers Loaded with Mycophenolic Acid to Be Studied as New Potential Immunosuppressants
}

\author{
Lorenzo Guazzelli, ${ }^{1,2}$ Felicia D'Andrea, ${ }^{1}$ Francesco Giorgelli, ${ }^{1}$ Giorgio Catelani, \\ Alessandra Panattoni, ${ }^{3}$ and Andrea Luvisi ${ }^{3}$ \\ ${ }^{1}$ Department of Pharmacy, University of Pisa, Via Bonanno 33, 56126 Pisa, Italy \\ ${ }^{2} S$ chool of Chemistry and Chemical Biology, University College Dublin, Belfield, Dublin 4, Ireland \\ ${ }^{3}$ Department of Agriculture, Food and Environment, University of Pisa, Via del Borghetto 80, 56124 Pisa, Italy
}

Correspondence should be addressed to Lorenzo Guazzelli; lorenzo.guazzelli@ucd.ie and

Felicia D’Andrea; felicia.dandrea@farm.unipi.it

Received 17 February 2015; Accepted 19 April 2015

Academic Editor: Albert Demonceau

Copyright (C) 2015 Lorenzo Guazzelli et al. This is an open access article distributed under the Creative Commons Attribution License, which permits unrestricted use, distribution, and reproduction in any medium, provided the original work is properly cited.

\begin{abstract}
The terminal $N$-Boc protected diamino PAMAM 7 was condensed (EDC-DMAP) with two units of mycophenolic acid (MPA) giving the $N$-Boc protected dendron 8 in a good yield (76\%). The ammonium trifluoroacetate 9 was prepared from 8 by acid treatment (TFA-THF- $\mathrm{H}_{2} \mathrm{O}$ ) and was split into two equal parts. The first half was treated with di-2-pyridyl thionocarbonate (DPT) in the presence of $\mathrm{Et}_{3} \mathrm{~N}$ to give the corresponding isothiocyanate 10. This was reacted with the second half of $\mathbf{9}$ providing the symmetrical dendrimer 11 (68\% yield), exposing four MPA units around the thioureido-PAMAM core.
\end{abstract}

\section{Introduction}

Mycophenolic acid (MPA, $\mathbf{1}$ ) is a potent inhibitor of inosine monophosphate dehydrogenase (IMPDH), a key enzyme in the de novo synthesis of guanine nucleotide [1]. MPA exhibits antiproliferation activity and has been established as an anticancer agent, an immunosuppressant $[1,2]$ as well as an antiviral drug against some plant viruses [3-5]. Among these promising properties of MPA, the immunosuppressant property is by far the most important. MPA is a cornerstone immunosuppressant used to prevent rejection after organ transplantation. Currently, two MPA derivatives are used clinically for this purpose (Figure 1): mycophenolate sodium (MPS, Myfortic, 2) and mycophenolate mofetil (MMF, CellCept, 3). Several structural modification of MPA were carried out during the last twenty years to advance the elucidation of the structure-activity relationship of MPA in its interaction with IMPDH and contributed to the understanding of the relevant sites required for drug activity. Analogues which displayed similar or better immunosuppressive activity were reported. These derivatives present modifications only at the terminal carboxylic acid [6-11].

In the search of new immunosuppressants, we planned the preparation of a new family of MPA derivatives linking more units of MPA to a scaffold by means of the carboxylic group. Among the possible scaffolds, we decided to use dendrimers as a drug delivery system (4, Figure 1) [12]. These are nanostructured macromolecules characterized by a tree-like architecture with exponential numbers of discrete dendritic branches radiating out from a common core. One of the most commonly known dendrimeric structure is the poly(amidoamine) (PAMAM) dendrimer which was introduced and developed by Tomalia and Fréchet [13]. PAMAM dendrimers are monodispersed, biocompatible, and synthetic macromolecules with well-defined structural architecture and composition. Here, we present the synthesis of PAMAM derivatives decorated with MPA units. The antiviral activity of these compounds has been recently tested in Nicotiana tabacum L. cv. Xanthi explants infected with a cucumber mosaic virus [14]. 
<smiles>COc1c(C)c2c(c(O)c1C/C=C(\C)CCC(=O)O)C(=O)OC2</smiles>

1<smiles>COc1c(C)c2c(c(O)c1C/C=C(\C)CCC(=O)O)C(=O)OC2</smiles>

2<smiles>COc1c(C)c2c(c(O)c1C/C=C(\C)CCC(=O)OCCN1CCOCC1)C(=O)OC2</smiles>

3

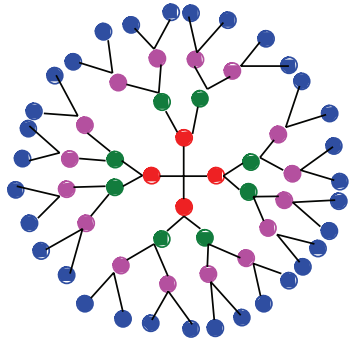

4

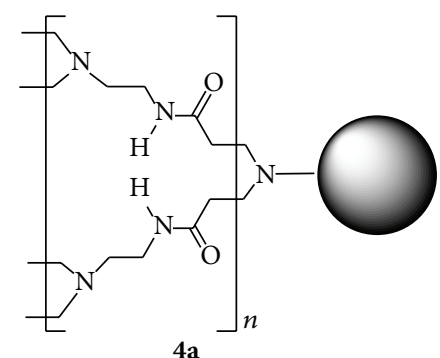

FIGURE 1: Mycophenolic acid (1) and its marketed derivatives (2) and (3); schematic representation of the structure of a generic dendrimer (4) and of a single PAMAM branch (4a).

\section{Experimental}

Melting points were determined with a Kofler hot-stage apparatus and are uncorrected. Optical rotations were measured with a Perkin-Elmer 241 polarimeter at $20 \pm 2{ }^{\circ} \mathrm{C} .{ }^{1} \mathrm{H}$ $\mathrm{NMR}$ and ${ }^{13} \mathrm{C}$ NMR spectra were recorded in appropriate solvents with a Bruker Avance II spectrometer operating at $250.12 \mathrm{MHz}\left({ }^{1} \mathrm{H}\right)$ and $62.9 \mathrm{MHz}\left({ }^{13} \mathrm{C}\right)$. Spin resonances were reported as chemical shifts $(\delta)$ in part per million (ppm) and the references to the residual peak of the solvent employed as follows: $\mathrm{CD}_{3} \mathrm{CN} 1.94 \mathrm{ppm}\left({ }^{1} \mathrm{H} \mathrm{NMR}\right.$, central band) and $1.28 \mathrm{ppm}\left({ }^{13} \mathrm{C} \mathrm{NMR}\right.$, central band), $\mathrm{CD}_{3} \mathrm{OD} 3.31 \mathrm{ppm}\left({ }^{1} \mathrm{H}\right.$ NMR, central band) and $49.0 \mathrm{ppm}\left({ }^{13} \mathrm{C}\right.$ NMR, central band). Spin multiplicity was indicated by $\mathrm{s}=$ singlet, $\mathrm{d}=$ doublet, $\mathrm{t}=$ triplet, $\mathrm{bt}=$ broad triplet, $\mathrm{q}=$ quartet, $\mathrm{m}=$ multiplet. Coupling constants $J$ were reported in Hertz $(\mathrm{Hz})$. The assignments were made, when possible, with the aid of DEPT, HETCOR, COSY, and HSQC experiments. Low resolution mass spectra were recorded on a LCQ Advantage ThermoFinnigan spectrometer equipped with an ion trap analyzer (Thermo Electron Company, San Jose, CA, USA). All reactions were followed by TLC on Kieselgel $60 \mathrm{~F}_{254}$ with detection by UV light and/or with ethanolic 10\% phosphomolybdic or sulfuric acid and heating. Kieselgel 60 (E. Merck, 70-230 and 230-400 mesh, resp.) was used for column and flash chromatography. Solvents were dried and purified by distillation according to standard procedure [15] and stored over $4 \AA$ molecular sieves activated for at least $24 \mathrm{~h}$ at $200^{\circ} \mathrm{C} . \mathrm{MgSO}_{4}$ was used as the drying agent for solutions. Compounds 5 and 7 were prepared according to the reported procedures [16].

2.1. Synthesis of Compound 6. A solution of mycophenolic acid (1) (125 mg, $0.390 \mathrm{mmol}, 1.2 \mathrm{eq})$ and amine 5 (57 mg, $0.354 \mathrm{mmol})$ in dry DMF $(1.5 \mathrm{~mL})$ containing $\mathrm{Et}_{3} \mathrm{~N}(148 \mu \mathrm{L}$, $1.06 \mathrm{mmol}, 3.0 \mathrm{eq})$ was treated at room temperature with 1-ethyl-3-(3-(dimethylamino)-propyl)-carbodiimide hydrochloride (EDC, $90.4 \mathrm{mg}, 0.472 \mathrm{mmol}, 1.34 \mathrm{eq}$ ) and $N$ hydroxybenzotriazole (HOBt, $49.2 \mathrm{mg}, 0.364 \mathrm{mmol}, 1.03 \mathrm{eq}$ ). The solution was stirred at room temperature until TLC analysis $\left(9: 1 \mathrm{CH}_{2} \mathrm{Cl}_{2}-\mathrm{MeOH}, 21 \mathrm{~h}\right.$ ) revealed the complete disappearance of amine 5 and the formation of a major product $\left(R_{f}=0.85\right)$. The mixture was concentrated under diminished pressure and the purification of the residue by flash chromatography over silica gel (2:8 hexane-EtOAc) gave pure $6\left(120 \mathrm{mg}, 73 \%\right.$ calculated from 5) as a solid foam; $R_{f}=$ 0.22 (2: 8 hexane-EtOAc); ${ }^{1} \mathrm{H}$ NMR (250.12 MHz, $\mathrm{CD}_{3} \mathrm{CN}-$ $\left.\mathrm{CDCl}_{3}\right): \delta 1.38\left[\mathrm{~s}, 9 \mathrm{H}, \mathrm{C}\left(\mathrm{CH}_{3}\right)_{3}\right], 1.92\left(\mathrm{~s}, 3 \mathrm{H},=\mathrm{CCH}_{3}\right), 2.10(\mathrm{~s}$, $\left.3 \mathrm{H}, \mathrm{Ar}-\mathrm{CH}_{3}\right), 2.18-2.24\left(\mathrm{~m}, 4 \mathrm{H},=\mathrm{C}\left(\mathrm{CH}_{2}\right)_{2} \mathrm{CO}\right), 2.98(\mathrm{q}, 2 \mathrm{H}, \mathrm{J}$ $\left.=5.7 \mathrm{~Hz}, \mathrm{CH}_{2} \mathrm{NHCO}\right), 3.10\left(\mathrm{q}, 2 \mathrm{H}, J=5.7 \mathrm{~Hz}, \mathrm{CH}_{2} \mathrm{NHCOO}\right)$, $3.34\left(\mathrm{~d}, 2 \mathrm{H}, \mathrm{J}=7.0 \mathrm{~Hz}, \mathrm{ArCH}_{2} \mathrm{CH}=\right), 3.73\left(\mathrm{~s}, 3 \mathrm{H}, \mathrm{CH}_{3}\right)$, 5.20 (s, $2 \mathrm{H}, \mathrm{ArCH}_{2} \mathrm{OCO}$ ), 5.17 (t, $1 \mathrm{H}, J=7.0 \mathrm{~Hz}, \mathrm{CH}=\mathrm{C}$ ), 5.42 (bt, 1H, NHCO), 6.53 (bt, 1H, NHCOO), 7.74 (s, 1H, $\mathrm{OH}) ;{ }^{13} \mathrm{C} \mathrm{NMR}\left(62.9 \mathrm{MHz}, \mathrm{CD}_{3} \mathrm{CN}-\mathrm{CDCl}_{3}\right): \delta 11.6(\mathrm{Ar}-$ $\left.\mathrm{CH}_{3}\right), 16.3\left(=\mathrm{CCH}_{3}\right), 23.1\left(\mathrm{ArCH}_{2} \mathrm{CH}=\right), 28.5\left[\mathrm{C}\left(\mathrm{CH}_{3}\right)_{3}\right]$, $35.4,35.8\left(=\mathrm{C}\left(\mathrm{CH}_{2}\right)_{2} \mathrm{CO}\right), 40.0,40.9\left[\mathrm{HN}\left(\mathrm{CH}_{2}\right)_{2} \mathrm{NH}\right], 61.5$ $\left(\mathrm{OCH}_{3}\right), 70.8\left(\mathrm{ArCH}_{2} \mathrm{O}\right), 79.3\left[\mathrm{C}\left(\mathrm{CH}_{3}\right)_{3}\right], 107.2(\mathrm{C}=), 123.3$ $(\mathrm{CH}=), 116.0,122.5,135.3,145.8(4 \times \operatorname{Ar}-\mathrm{C}), 157.0(\mathrm{O}-\mathrm{C}=\mathrm{O})$, 153.8, $164.2(2 \times$ Ar-C-O $), 173.2,173.6(2 \times \mathrm{C}=\mathrm{O})$. ESIMS: calcd for $\mathrm{C}_{24} \mathrm{H}_{34} \mathrm{~N}_{2} \mathrm{O}_{7} \mathrm{Na}[\mathrm{M}+\mathrm{Na}]^{+}$485.5, found 485.3. Anal. Calcd for $\mathrm{C}_{24} \mathrm{H}_{34} \mathrm{~N}_{2} \mathrm{O}_{7}$ : C, 62.32; H, 7.41; N, 6.06. Found: C, $62.34 ; \mathrm{H}, 7.44 ; \mathrm{N}, 6.08$.

\subsection{Synthesis of Compound $\mathbf{8}$}

Method A (EDC, HOBT, Et ${ }_{3} N$, and DMF). A solution of mycophenolic acid (1) (369 mg, $1.151 \mathrm{mmol}, 1.2 \mathrm{eq})$ and amine 7 (204 mg, $0.525 \mathrm{mmol})$ in dry DMF $(6.0 \mathrm{~mL})$ containing $\mathrm{Et}_{3} \mathrm{~N}(48 \mu \mathrm{L}, 3.48 \mathrm{mmol}, 3.0 \mathrm{eq})$ was treated at room temperature with EDC (296 mg, $0.514 \mathrm{mmol}, 1.33 \mathrm{eq})$ and $\mathrm{HOBt}$ (161 mg, $1.19 \mathrm{mmol}, 1.03 \mathrm{eq}$ ) and the solution was stirred at 
room temp. After $48 \mathrm{~h}$, TLC analysis $\left(8: 2 \mathrm{CH}_{2} \mathrm{Cl}_{2}-\mathrm{MeOH}\right)$ revealed the complete disappearance of amine 7 and the formation of a major product $\left(R_{f}=0.71\right)$. The mixture was concentrated under diminished pressure and the purification of the residue by flash chromatography over silica gel $(88: 12$ $\left.\mathrm{CH}_{2} \mathrm{Cl}_{2}-\mathrm{MeOH}\right)$ gave pure $8(298 \mathrm{mg}, 57 \%$ calculated from 7).

Method B (EDC, DMAP, and DMF). A solution of amine 7 (98.4 mg, $0.253 \mathrm{mmol}$ ) and mycophenolic acid (1) (179 mg, $0.558 \mathrm{mmol}, 2.2 \mathrm{eq})$ in dry DMF $(3 \mathrm{~mL})$ was treated with EDC (130 mg, $0.676 \mathrm{mmol}, 2.67 \mathrm{eq}$ ) and 4-dimethylaminopyridine (DMAP, $9.3 \mathrm{mg}, 0.0759 \mathrm{mmol}, 0.3 \mathrm{eq}$ ). The mixture was stirred at room temperature and after $48 \mathrm{~h}$ the TLC analysis (9:1 $\left.\mathrm{CH}_{2} \mathrm{Cl}_{2}-\mathrm{MeOH}\right)$ revealed the complete disappearance of amine 7 and the formation of a major product $\left(R_{f}=0.40\right)$. The mixture was concentrated under diminished pressure and the purification of the residue by flash chromatography over silica gel $\left(\mathrm{CH}_{2} \mathrm{Cl}_{2}-\mathrm{MeOH} 92: 8\right)$ gave pure $8(191 \mathrm{mg}$, $76 \%)$.

Compound 8 was a solid foam; $R_{f}=0.12$ (92:8 $\left.\mathrm{CH}_{2} \mathrm{Cl}_{2}-\mathrm{MeOH}\right) ;{ }^{1} \mathrm{H}$ NMR $\left(250.12 \mathrm{MHz}, \mathrm{CD}_{3} \mathrm{OD}-\mathrm{CDCl}_{3}\right)$ : $\delta 1.40\left[\mathrm{~s}, 9 \mathrm{H}, \mathrm{C}\left(\mathrm{CH}_{3}\right)_{3}\right], 1.80\left(\mathrm{~s}, 6 \mathrm{H}, 2 \times=\mathrm{CCH}_{3}\right), 2.13$ $\left(\mathrm{s}, 6 \mathrm{H}, 2 \times \mathrm{Ar}-\mathrm{CH}_{3}\right), 2.30$ (bt, $4 \mathrm{H}, J=6.3 \mathrm{~Hz}, 2 \times$ $\left.\mathrm{NCH}_{2} \mathrm{CH}_{2} \mathrm{CONH}\right), 2.32$ (bs, $\left.8 \mathrm{H}, 2 \times=\mathrm{C}\left(\mathrm{CH}_{2}\right)_{2} \mathrm{CO}\right)$, $2.50\left(\mathrm{t}, 2 \mathrm{H}, \mathrm{J}=6.8 \mathrm{~Hz}, \mathrm{NCH}_{2} \mathrm{CH}_{2} \mathrm{NHCOO}\right), 2.75(\mathrm{bt}$, $\left.4 \mathrm{H}, J=6.3 \mathrm{~Hz}, 2 \times \mathrm{NCH}_{2} \mathrm{CH}_{2} \mathrm{CONH}\right), 3.15(\mathrm{t}, 2 \mathrm{H}$, $\left.J=6.8 \mathrm{~Hz}, \mathrm{NCH}_{2} \mathrm{CH}_{2} \mathrm{NHCOO}\right), 3.30[\mathrm{~m}, 8 \mathrm{H}, 2 \times$ $\left.\mathrm{CONH}\left(\mathrm{CH}_{2}\right)_{2} \mathrm{NHCO}\right], 3.36(\mathrm{~d}, 4 \mathrm{H}, J=6.6 \mathrm{~Hz}, 2 \times$ $\left.\mathrm{ArCH}_{2} \mathrm{CH}=\right), 3.75\left(\mathrm{~s}, 6 \mathrm{H}, 2 \times \mathrm{OCH}_{3}\right), 5.41(\mathrm{~m}, 6 \mathrm{H}, 2 \times$ $\left.\mathrm{CH}=\mathrm{C}, 2 \times \mathrm{ArCH}_{2} \mathrm{OCO}\right) ;{ }^{13} \mathrm{C} \mathrm{NMR}\left(62.9 \mathrm{MHz}, \mathrm{CD}_{3} \mathrm{OD}-\right.$ $\left.\mathrm{CDCl}_{3}\right): \delta 11.6\left(2 \times \mathrm{ArCH}_{3}\right), 23.5\left(2 \times \mathrm{ArCH}_{2} \mathrm{CH}=\right), 16.3(2 \times$ $\left.=\mathrm{CCH}_{3}\right), 33.4\left(2 \times \mathrm{NCH}_{2} \mathrm{CH}_{2} \mathrm{CONH}\right), 28.7\left[\mathrm{C}\left(\mathrm{CH}_{3}\right)_{3}\right], 35.6$, $36.3\left(2 \times=\mathrm{C}\left(\mathrm{CH}_{2}\right)_{2} \mathrm{CO}\right), 39.8,39.7\left[2 \times \mathrm{HN}\left(\mathrm{CH}_{2}\right)_{2} \mathrm{NH}\right], 38.4$ $\left(\mathrm{NCH}_{2} \mathrm{CH}_{2} \mathrm{NHCOO}\right), 50.8\left(2 \times \mathrm{NCH}_{2} \mathrm{CH}_{2} \mathrm{CONH}\right), 53.1$ $\left(\mathrm{NCH}_{2} \mathrm{CH}_{2} \mathrm{NHCOO}\right), 61.5\left(2 \times \mathrm{OCH}_{3}\right), 70.7\left(2 \times \mathrm{ArCH}_{2} \mathrm{O}\right)$, $\left.80.1\left[\mathrm{C}_{\left(\mathrm{CH}_{3}\right.}\right)_{3}\right], 107.5(2 \times \mathrm{C}=), 123.9(2 \times \mathrm{CH}=), 117.7,123.3$, $134.8,145.8(8 \times \mathrm{Ar}-\mathrm{C}), 158.1(\mathrm{O}-\mathrm{C}=\mathrm{O}), 154.5,164.6(4 \times$ Ar-C-O), 173.6, 174.3, $175.6(6 \times \mathrm{C}=\mathrm{O})$. ESIMS: calcd for $\mathrm{C}_{51} \mathrm{H}_{72} \mathrm{~N}_{2} \mathrm{O}_{14} \mathrm{Na}[\mathrm{M}+\mathrm{Na}]^{+}$1015.5, found 1015.4. Anal. Calcd for $\mathrm{C}_{51} \mathrm{H}_{72} \mathrm{~N}_{6} \mathrm{O}_{14}$ : C, 61.68; H, 7.31; N, 8.46. Found: C, 61.70; $\mathrm{H}, 7.33 ; \mathrm{N}, 8.47$.

2.3. Synthesis of Dendrimer 11. A solution of $8(186 \mathrm{mg}$, $0.186 \mathrm{mmol})$ in $\mathrm{CH}_{2} \mathrm{Cl}_{2}-\mathrm{TFA}-\mathrm{H}_{2} \mathrm{O} 7.4: 2.4: 0.2(2.0 \mathrm{~mL})$ was stirred at room temperature until the TLC analysis $(8: 2$ $\mathrm{CH}_{2} \mathrm{Cl}_{2}-\mathrm{MeOH}, 1 \mathrm{~h}$ ) revealed the complete disappearance of the starting material and the formation of a major product $\left(R_{f}=0.36\right)$. The reaction mixture was concentrated under diminished pressure and repeatedly coevaporated with toluene $(4 \times 30 \mathrm{~mL})$. The crude residue $(184 \mathrm{mg})$ analyzed by NMR proved to be constituted only by the ammonium trifluoroacetate 9. The salt 9 is a solid foam, $R_{f}=0.36(8: 2$ $\left.\mathrm{CH}_{2} \mathrm{Cl}_{2}-\mathrm{MeOH}\right) ;{ }^{1} \mathrm{H}$ NMR $\left(250.12 \mathrm{MHz}, \mathrm{CD}_{3} \mathrm{CN}\right): \delta 1.77$ (s, $\left.6 \mathrm{H}, 2 \times=\mathrm{CCH}_{3}\right), 2.10\left(\mathrm{~s}, 6 \mathrm{H}, 2 \times \mathrm{Ar}-\mathrm{CH}_{3}\right), 2.70$ (bs, $4 \mathrm{H}, 2 \times$ $\left.\mathrm{NCH}_{2} \mathrm{CH}_{2} \mathrm{CONH}\right), 2.18-2.30\left(\mathrm{~m}, 12 \mathrm{H}, 2 \times=\mathrm{C}\left(\mathrm{CH}_{2}\right)_{2} \mathrm{CO}, 2 \times\right.$ $\left.\mathrm{NCH}_{2} \mathrm{CH}_{2} \mathrm{CONH}\right), 3.05\left(\mathrm{~m}, 2 \mathrm{H}, \mathrm{NCH}_{2} \mathrm{CH}_{2} \mathrm{NH}_{3}{ }^{+}\right), 3.32(\mathrm{~d}$, $\left.4 \mathrm{H}, J=6.8 \mathrm{~Hz}, 2 \times \mathrm{ArCH}_{2} \mathrm{CH}=\right), 3.20,3.40[2 \mathrm{~m}$, each $4 \mathrm{H}$, $\left.2 \times \mathrm{CONH}\left(\mathrm{CH}_{2}\right)_{2} \mathrm{NHCO}\right], 3.44\left(\mathrm{~m}, 2 \mathrm{H}, \mathrm{CH}_{2} \mathrm{NH}_{3}{ }^{+}\right), 3.72(\mathrm{~s}$, $\left.6 \mathrm{H}, 2 \times \mathrm{OCH}_{3}\right), 5.16\left(\mathrm{~m}, 6 \mathrm{H}, 2 \times \mathrm{CH}=\mathrm{C}, 2 \times \mathrm{ArCH}_{2} \mathrm{OCO}\right)$, 10.1 (bs, $4 \mathrm{H}, 4 \times \mathrm{NHCO}), 7.80(\mathrm{~s}, 2 \mathrm{H}, 2 \times \mathrm{OH}) ;{ }^{13} \mathrm{C} \mathrm{NMR}$ $\left(62.9 \mathrm{MHz}, \mathrm{CD}_{3} \mathrm{CN}\right): \delta 11.6\left(2 \times \mathrm{Ar}-\mathrm{CH}_{3}\right), 16.2\left(2 \times=\mathrm{CCH}_{3}\right)$, $23.3\left(2 \times \mathrm{ArCH}_{2} \mathrm{CH}=\right), 29.1\left(2 \times \mathrm{NCH}_{2} \mathrm{CH}_{2} \mathrm{CONH}\right), 35.9,36.4$ $\left(2 \times=\mathrm{C}\left(\mathrm{CH}_{2}\right)_{2} \mathrm{CO}\right), 38.7,39.9\left[2 \times \mathrm{HN}\left(\mathrm{CH}_{2}\right)_{2} \mathrm{NH}\right], 51.9(2 \times$ $\left.\mathrm{NCH} \mathrm{CH}_{2} \mathrm{CONH}\right), 36.4\left(\mathrm{CH}_{2} \mathrm{NHCO}\right), 50.1\left(\mathrm{CH}_{2} \mathrm{NH}_{3}{ }^{+}\right)$, $61.6\left(2 \times \mathrm{OCH}_{3}\right), 71.0\left(2 \times \mathrm{ArCH}_{2} \mathrm{O}\right), 123.8(2 \times \mathrm{CH}=), 107.3$ $(2 \times \mathrm{C}=), 119.0,122.7,135.2,146.2(8 \times \mathrm{Ar}-\mathrm{C}), 153.9,164.3(4 \times$ Ar-CO), 173.0, 176.0, $173.4(6 \times \mathrm{C}=\mathrm{O})$.

To a solution of crude $9(92 \mathrm{mg}, 0.0912 \mathrm{mmol})$ in dry $\mathrm{CH}_{2} \mathrm{Cl}_{2}(1.4 \mathrm{~mL}), \mathrm{Et}_{3} \mathrm{~N}(100 \mu \mathrm{L})$ and 2-pyridyl thiocarbonate (DPT, $22 \mathrm{mg}, 0.0912 \mathrm{mmol}$ ) were added at room temperature. After $6 \mathrm{~h}$ the TLC analysis $\left(7: 3 \mathrm{EtOAc-}{ }^{\mathrm{i}} \mathrm{prOH}\right)$ revealed the complete disappearance of the starting material and the formation of a major product $\left(R_{f}=0.24\right)$. The solution was concentrated under diminished pressure and the crude isothiocyanate intermediate $10(86 \mathrm{mg}, 0.0912 \mathrm{mmol})$ was solubilized in dry $1: 1 \mathrm{CH}_{2} \mathrm{Cl}_{2}$-DMF $(1.0 \mathrm{~mL})$ and a solution of crude 9 (92 mg, $0.0912 \mathrm{mmol}$ ) in dry $1: 1 \mathrm{CH}_{2} \mathrm{Cl}_{2}$-DMF $(2.0 \mathrm{~mL})$ containing $\mathrm{Et}_{3} \mathrm{~N}(0.2 \mathrm{~mL})$ was added dropwise. The reaction mixture was stirred at room temperature for $43 \mathrm{~h}$, until TLC analysis $\left(7: 3\right.$ EtOAc- ${ }^{\mathrm{i}}$ prOH) revealed the formation of a major product at $R_{f}=0.22$. The reaction was concentrated at reduced pressure and the crude was subjected to a flash chromatography (EtOAc) on silica gel to give dendrimer 11 (114 mg, 68\% from 9) as a foam solid; $R_{f}=$ 0.22 (7:3 EtOAc- ${ }^{\mathrm{i}}$ prOH) ${ }^{1}{ }^{1} \mathrm{H}$ NMR $\left(250.12 \mathrm{MHz}, \mathrm{CD}_{3} \mathrm{OD}-\right.$ $\left.\mathrm{CDCl}_{3}\right): \delta 1.81\left(\mathrm{~s}, 12 \mathrm{H}, 4 \times=\mathrm{CCH}_{3}\right), 2.14(\mathrm{~s}, 12 \mathrm{H}, 4 \times$ $\left.\mathrm{Ar}-\mathrm{CH}_{3}\right), 2.26$ [bs, $16 \mathrm{H}, 4 \times=\mathrm{C}\left(\mathrm{CH}_{2}\right)_{2} \mathrm{CO}$ ], 2.34 (bt, $8 \mathrm{H}$, $\left.J=6.4 \mathrm{~Hz}, 4 \times \mathrm{NCH}_{2} \mathrm{CH}_{2} \mathrm{CONH}\right), 2.72-2.86(\mathrm{~m}, 12 \mathrm{H}, 2 \times$ $\left.\mathrm{NCH}_{2} \mathrm{CH}_{2} \mathrm{NHCS}, 4 \times \mathrm{NCH}_{2} \mathrm{CH}_{2} \mathrm{CONH}\right), 3.22[\mathrm{~m}, 16 \mathrm{H}$, $\left.4 \times \mathrm{CONH}\left(\mathrm{CH}_{2}\right)_{2} \mathrm{NHCO}\right], 3.37(\mathrm{~d}, 8 \mathrm{H}, J=7.0 \mathrm{~Hz}, 4 \times$ $\left.\mathrm{ArCH}_{2} \mathrm{CH}=\right), 3.58\left(\mathrm{t}, 4 \mathrm{H}, \mathrm{J}=5.6 \mathrm{~Hz}, \mathrm{NCH}_{2} \mathrm{CH}_{2} \mathrm{NHCS}\right), 3.76$ $\left(\mathrm{s}, 12 \mathrm{H}, 4 \times \mathrm{OCH}_{3}\right), 5.21\left(\mathrm{~s}, 8 \mathrm{H}, 4 \times \mathrm{ArCH}_{2} \mathrm{OCO}\right), 5.24(\mathrm{t}, 4 \mathrm{H}$, $J=7.3 \mathrm{~Hz}, 4 \times \mathrm{CH}=\mathrm{C}) ;{ }^{13} \mathrm{C} \mathrm{NMR}\left(62.9 \mathrm{MHz}, \mathrm{CD}_{3} \mathrm{CN}-\mathrm{D}_{2} \mathrm{O}\right): \delta$ $11.5\left(4 \times \mathrm{Ar}^{-} \mathrm{CH}_{3}\right) .16 .3\left(4 \times=\mathrm{CCH}_{3}\right), 23.5\left(4 \times \mathrm{ArCH}_{2} \mathrm{CH}=\right)$, $34.8\left(4 \times \mathrm{NCH}_{2} \mathrm{CH}_{2} \mathrm{CONH}\right), 35.8,36.4\left[4 \times=\mathrm{C}\left(\mathrm{CH}_{2}\right)_{2} \mathrm{CO}\right]$, $39.9\left[4 \times \mathrm{HN}\left(\mathrm{CH}_{2}\right)_{2} \mathrm{NH}\right], 44.3\left(\mathrm{NCH}_{2} \mathrm{CH}_{2} \mathrm{NHCS}\right), 50.8(4 \times$ $\left.\mathrm{NCH}_{2} \mathrm{CH}_{2} \mathrm{CONH}\right), 54.2\left(2 \times \mathrm{NCH}_{2} \mathrm{CH}_{2} \mathrm{NHCS}\right), 61.5(4 \times$ $\left.\mathrm{OCH}_{3}\right), 70.7\left(4 \times \mathrm{ArCH}_{2} \mathrm{O}\right), 107.5(4 \times \mathrm{C}=), 117.6,123.4,134.9$, $146.2(16 \times \mathrm{Ar}-\mathrm{C}), 124.3(4 \times \mathrm{CH}=), 154.5,164.5(8 \times \mathrm{Ar}-\mathrm{C}-$ O), 173.6, 174.7, $175.7(12 \times \mathrm{C}=\mathrm{O}), 179.8(\mathrm{C}=\mathrm{S})$. ESIMS: calcd for $\mathrm{C}_{93} \mathrm{H}_{126} \mathrm{~N}_{12} \mathrm{O}_{24} \mathrm{SNa}[\mathrm{M}+\mathrm{Na}]^{+}$1849.9, found 1849.7. Anal. Calcd for $\mathrm{C}_{93} \mathrm{H}_{126} \mathrm{~N}_{12} \mathrm{O}_{24} \mathrm{~S}$ : C, 61.10; H, 6.95; N, 9.19. Found: C, $61.13 ; \mathrm{H}, 6.98 ; \mathrm{N}, 9.21$.

\section{Results and Discussion}

Derivative 6 was first prepared, as a positive control for biological evaluations (Scheme 1). The monoprotected $\mathrm{N}$ Boc-ethylenediamine 5 [16], which is also used as the central core in the construction of PAMAM dendrons, was used as capping reagent. The same kind of additional functional groups will be present in all synthetic structures, thus ensuring similar interactions during the evaluation of immunosuppressant properties. 
<smiles>COc1c(C)c2c(c(O)c1C/C=C(\C)CCC(=O)O)C(=O)OC2</smiles>

SCHEME 1: Synthesis of compound 6.<smiles>COc1c(C)c2c(c(O)c1C/C=C(\C)CCC(=O)O)C(=O)OC2</smiles><smiles>CC(C)(C)OC(=O)NCCN(CCCN)CCC(=O)NCCN</smiles>

7

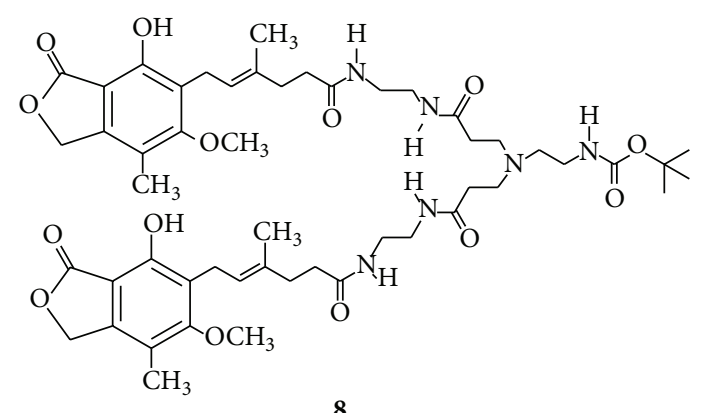

8

Scheme 2: Synthesis of compound 8. Reaction conditions: EDC, DMPA, DMF, room temperature, $48 \mathrm{~h}$ (76\% yield) or EDC, HOBt, DMF, $\mathrm{Et}_{3} \mathrm{~N}$, room temperature, $48 \mathrm{~h}$ ( $57 \%$ yield).

1-Ethyl-3-(3-dimethylaminopropyl) carbodiimide (EDC), which is nowadays preferred to $N, N^{\prime}$-dicyclohexylcarbodiimide (DCC) in the formation of amide bonds because it is not a skin sensitizer and its urea by-product can be easily removed, was chosen as a coupling agent and the reaction was carried out at room temperature in the presence of $\mathrm{N}$-hydroxybenzotriazole $(\mathrm{HOBt})$ and triethylamine $\left(\mathrm{Et}_{3} \mathrm{~N}\right)$. Compound 6 was isolated after $12 \mathrm{~h}$ in a $73 \%$ yield after flash chromatography on silica gel. The two-branched structure 7 [16] was easily obtained via double Michael addition of methyl acrylate to $\mathrm{N}$-Boc-ethylenediamine followed by amidation of the intermediate with a large excess of ethylenediamine. This was then reacted with 1 using the same coupling conditions seen above (Scheme 2). The reaction required longer time ( $48 \mathrm{~h}$ ) to go to completion and afforded 8 in a poor $57 \%$ yield. Better results were obtained when $\mathrm{N}, \mathrm{N}$-dimethylaminopyridine (DMAP) was used instead of the mixture $\mathrm{Et}_{3} \mathrm{~N}-\mathrm{HOBt}$. In this case, the desired compound was isolated in a $76 \%$ yield after chromatographic purification.

Having obtained this structure, the synthesis of the symmetrical dendrimer 11 was possible (Scheme 3). First, the acid labile $\mathrm{N}$-Boc protecting group was removed (trifluoroacetic acid-water, in $\mathrm{CH}_{2} \mathrm{Cl}_{2}$ ) giving the ammonium trifluoroacetate salt 9 in a quantitative yield. The structure and purity of 9 were confirmed by NMR analysis, which verified the complete removal of the $t$-butoxy carbonyl group. The latter compound was then reacted, without purification, with di-2-pyridyl thionocarbonate (DPT) and triethylamine. DPT $[17,18]$ is a commercially available, solid, nontoxic reagent that can be used in the preparation of isothiocyanates as a safe alternative to thiophosgene. The reaction proceeded smoothly and gave the complete conversion after $5.5 \mathrm{~h}$. The intermediate isothiocyanate obtained after removal of the solvents was directly reacted with crude 9 in the presence of $\mathrm{Et}_{3} \mathrm{~N}$ in a mixture of $\mathrm{CH}_{2} \mathrm{Cl}_{2}$ and DMF.

Dendrimer 11 was obtained after flash chromatographic purification in a satisfactory $68 \%$ overall yield. The symmetrical structure of compound $\mathbf{1 1}$ and the formation of the thioureido bridge (diagnostic $\mathrm{C}=\mathrm{S}$ signal) were fully confirmed by ${ }^{1} \mathrm{H},{ }^{13} \mathrm{C}$ and $2 \mathrm{D}$ NMR experiments.

\section{Conclusions}

In conclusion, we reported the synthesis of poly (amidoamine) structures decorated with mycophenolic acid. The target structures were prepared in good overall yields and with a limited number of purification steps. Furthermore, the very same strategy could be used to prepare dendrimers of higher generation. On the other hand, the presence of the orthogonally protected amino group on the inner core could allow for the preparation of a library of asymmetrical structures coupling the dendron with different compounds rather than its symmetrical counterpart. The immunosuppressant properties of these compounds are currently under investigation and the results will be published in due course.

\section{Conflict of Interests}

The authors declare that there is no conflict of interests regarding the publication of this paper. 


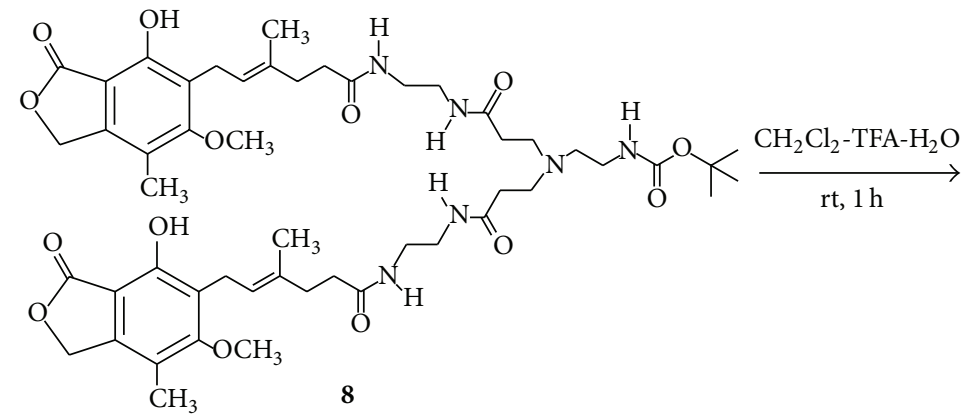

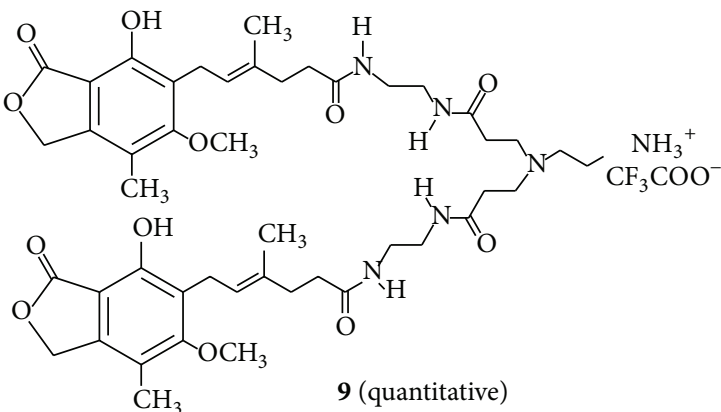<smiles>COc1c(C)c2c(c(O)c1C/C=C(\C)CCC(=O)NCCNC(=O)CCCN(CCN=C=S)CCC(=O)NCCNC(=O)CC/C(C)=C/Cc1c(O)c(C)c3c(c1O)C(=O)OC3)C(=O)OC2</smiles>

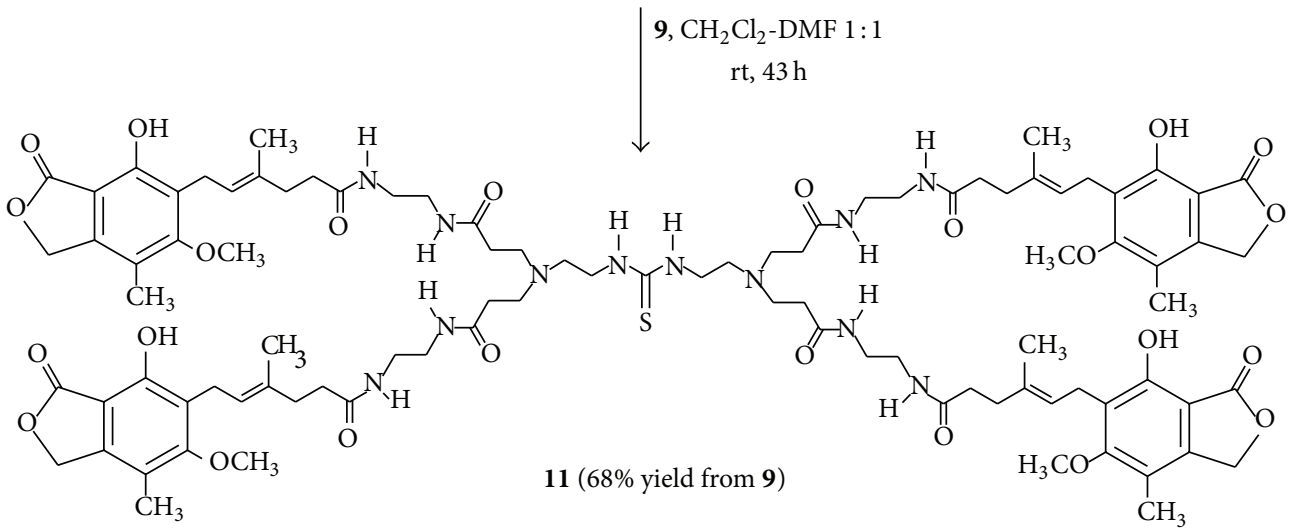

SCHeme 3: Synthesis of dendrimer 11.

\section{Acknowledgment}

Thanks are due to Dr. Stefania Fuselli who performed part of the experimental work in the frame of her undergraduate thesis.

\section{References}

[1] L. Chen, D. J. Wilson, N. P. Labello, H. N. Jayaram, and K. W. Pankiewicz, "Mycophenolic acid analogs with a modified metabolic profile," Bioorganic \& Medicinal Chemistry, vol. 16, no. 20, pp. 9340-9345, 2008.

[2] A. J. Ratcliffe, "Inosine $5^{\prime}$-monophosphate dehydrogenase inhibitors for the treatment of autoimmune diseases," Current Opinion in Drug Discovery \& Development, vol. 9, no. 5, pp. 595605, 2006.

[3] F. G. Skiada, K. Grigoriadou, V. I. Maliogka, N. I. Katis, and E. P. Eleftheriou, "Elimination of Grapevine leafroll-associated virus 1 and Grapevine rupestris stem pitting-associated virus from grapevine cv. Agiorgitiko, and a micropropagation protocol for mass production of virus-free plantlets," Journal of Plant Pathology, vol. 91, no. 1, pp. 177-184, 2009.

[4] F. G. Skiada, V. I. Maliogka, N. I. Katis, and E. P. Eleftheriou, "Elimination of Grapevine rupestris stem pitting-associated virus (GRSPaV) from two Vitis vinifera cultivars by in vitro chemotherapy," European Journal of Plant Pathology, vol. 135, no. 2, pp. 407-414, 2013.

[5] A. Luvisi, E. Rinaldelli, A. Panattoni, and E. Triolo, "Membrane transport of antiviral drugs in plants: an electrophysiological study in grapevine explants infected by Grapevine leafroll associated virus 1," Acta Physiologiae Plantarum, vol. 34, no. 6, pp. 2115-2123, 2012.

[6] W. J. Watkins, J. M. Chen, A. Cho et al., "Phosphonic acidcontaining analogues of mycophenolic acid as inhibitors of IMPDH," Bioorganic \& Medicinal Chemistry Letters, vol. 16, no. 13, pp. 3479-3483, 2006.

[7] M. Fardis, M. Mertzman, W. Thomas et al., "Use of benzofuran for concomitant protection of aldehyde and phenol groups in the preparation of mycophenolic acid analogues," The Journal of Organic Chemistry, vol. 71, no. 13, pp. 4835-4839, 2006. 
[8] L. Chen, D. Wilson, H. N. Jayaram, and K. W. Pankiewicz, "Dual inhibitors of inosine monophosphate dehydrogenase and histone deacetylases for cancer treatment," Journal of Medicinal Chemistry, vol. 50, no. 26, pp. 6685-6691, 2007.

[9] J. C. Rohloff, J. O. Gardner, and R. W. Towne, "Mycophenolate dianions," Tetrahedron Letters, vol. 36, no. 43, pp. 7803-7806, 1995.

[10] D. B. Smith, A. M. Waltos, D. G. Loughhead et al., "Asymmetric synthesis and stereochemical assignment of RS-97613, a potent immunosuppressive and anti-inflammatory agent," Journal of Organic Chemistry, vol. 61, no. 6, pp. 2236-2241, 1996.

[11] D. Iwaszkiewicz-Grzes, G. Cholewinski, A. Kot-Wasik, P. Trzonkowski, and K. Dzierzbicka, "Synthesis and biological activity of mycophenolic acid-amino acid derivatives," European Journal of Medicinal Chemistry, vol. 69, pp. 863-871, 2013.

[12] J. Zhu and X. Shi, "Dendrimer-based nanodevices for targeted drug delivery applications," Journal of Materials Chemistry B, vol. 1, no. 34, pp. 4199-4211, 2013.

[13] D. A. Tomalia and J. M. J. Fréchet, "Discovery of dendrimers and dendritic polymers: a brief historical perspective," Journal of Polymer Science. Part A: Polymer Chemistry, vol. 40, no. 16, pp. 2719-2728, 2002.

[14] A. Panattoni, A. Luvisi, S. Fuselli et al., "Antiviral activity of mycophenolic acid derivatives in plants," Acta virologica, vol. 58, no. 1, pp. 99-102, 2014.

[15] D. D. Perrin, W. L. F. D. Armarego, and R. Perrin, Purification of Laboratory Chemicals, Pergamon Press, Oxford, UK, 2nd edition, 1980.

[16] W. Cao and L. Zhu, "Synthesis and unimolecular micelles of amphiphilic dendrimer-like star polymer with various functional surface groups," Macromolecules, vol. 44, no. 6, pp. 15001512, 2011.

[17] S. Kim and K. Y. Yi, "Di-2-Pyridyl thionocarbonate. A new reagent for the preparation of isothiocyanates and carbodiimides," Tetrahedron Letters, vol. 26, no. 13, pp. 1661-1664, 1985.

[18] N. Huh, A. A. Rege, B. Yoo, T. P. Kogan, and H. Kohn, "Design, synthesis, and evaluation of mitomycin-tethered phosphorothioate oligodeoxynucleotides," Bioconjugate Chemistry, vol. 7, no. 6, pp. 659-669, 1996. 

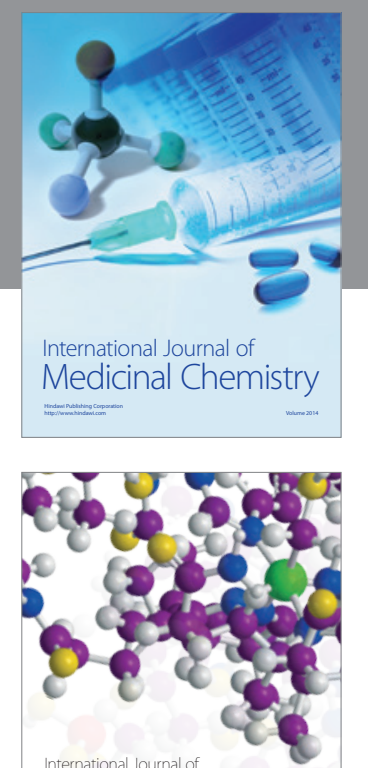

\section{Carbohydrate} Chemistry

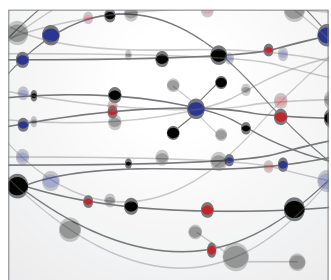

The Scientific World Journal
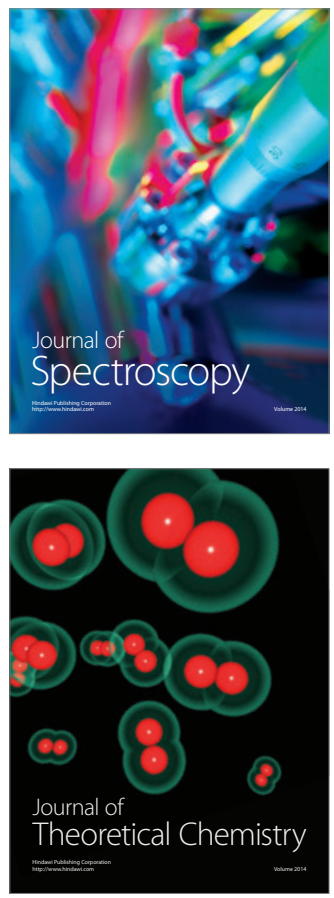
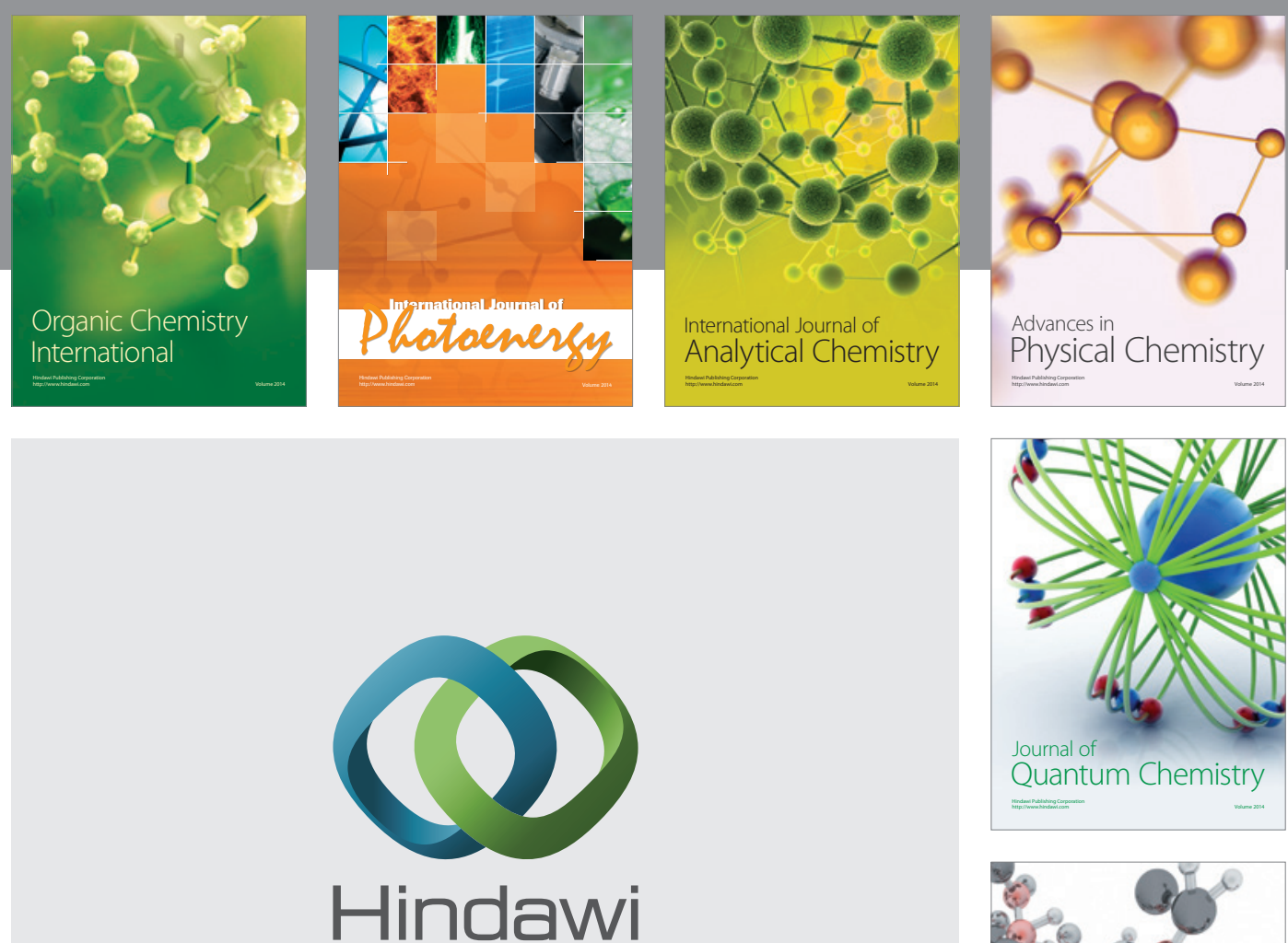

Submit your manuscripts at

http://www.hindawi.com

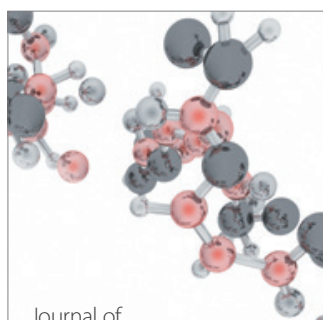

Analytical Methods

in Chemistry

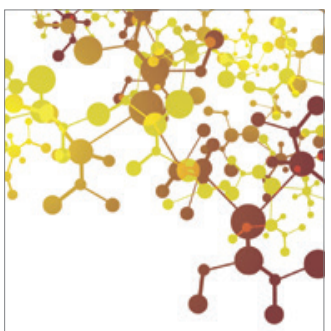

Journal of

Applied Chemistry

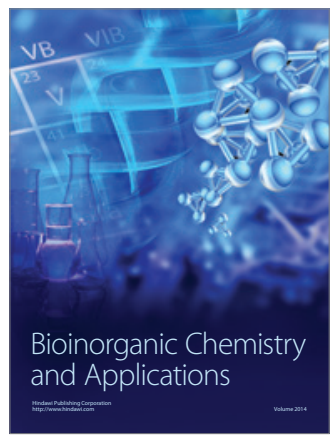

Inorganic Chemistry
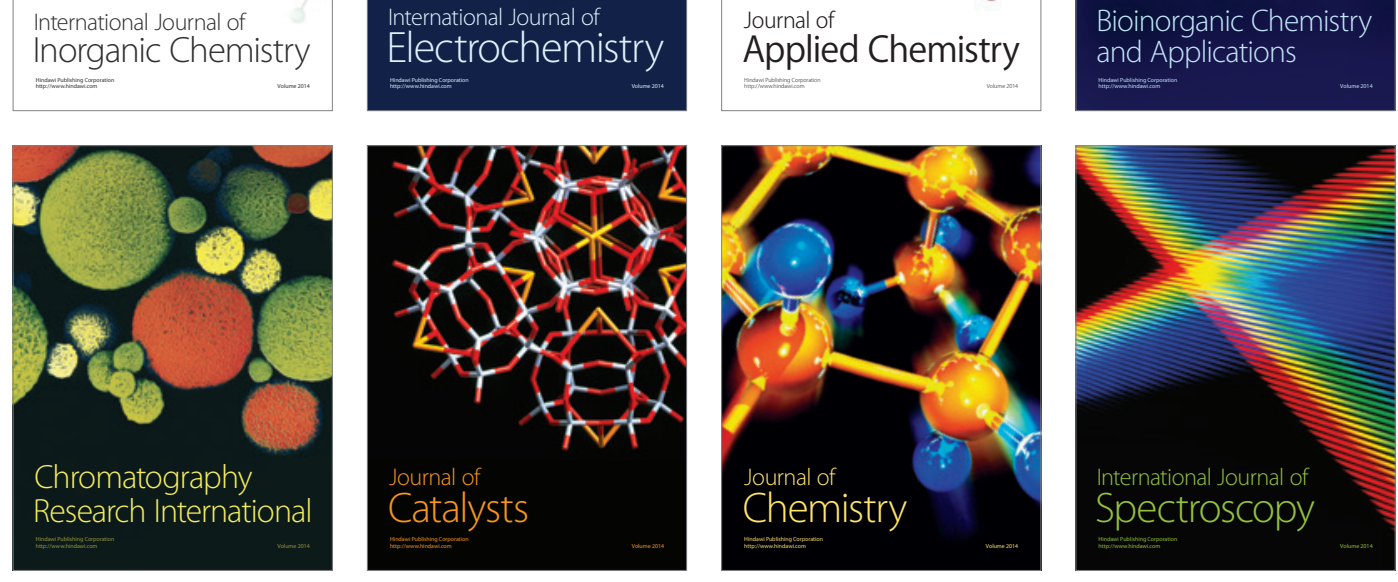